\title{
Expressão de genes da subfamília HD-Zip / em soja submetida à seca
}

\author{
Alan Alves Pereira(1), Aguida Maria Alves Pereira Morales ${ }^{(2)}$, Aluízio Borém ${ }^{(1)}$ e Marcelo Ehlers Loureiro(3) \\ (1)Universidade Federal de Viçosa (UFV), Departamento de Fitotecnia, Avenida P.H. Rolfs, s/no, CEP $36570-000$ Viçosa, MG. \\ E-mail: alanalvesp@gmail.com, borem@ufv.br (2)UFV, Departamento de Genética e Melhoramento. E-mail: aguidamorales@gmail.com \\ (3)UFV, Departamento de Biologia Vegetal. E-mail: mehlers@ufv.br
}

\begin{abstract}
Resumo - O objetivo deste trabalho foi identificar genes candidatos da subfamília de fatores transcricionais HD-Zip I que contribuem para a tolerância à seca em soja. Foram avaliados trifólios de soja de cultivar tolerante (Embrapa 48) e suscetível à seca (BR 16), sob três níveis de deficit hídrico: ausência, moderado (-1,5 MPa) e severo (-3,0 MPa). Pela análise dos promotores, foi identificada a presença de possíveis elementos cis-regulatórios relacionados à resposta à seca, nos três genes avaliados (GmHB6, GmHB13 e GmHB21). No entanto, não houve padrão de distribuição específico associado à maior tolerância do genótipo à seca. Com a análise comparativa, foram identificados seis elementos cis-regulatórios potencialmente envolvidos na indução da expressão gênica sob seca. O gene $G m H B 13$ foi exclusivamente induzido pela seca no genótipo tolerante, e o gene GmHB6 apresentou redução da expressão somente no genótipo suscetível. Já o gene GmHB21, apresentou aumento da expressão em ambos os genótipos. O gene GmHB13 é um importante elemento na regulação do mecanismo de tolerância à seca em soja, na cultivar tolerante Embrapa 48.
\end{abstract}

Termos para indexação: elementos cis-regulatórios, fatores transcricionais, genômica, PCR em tempo real.

\section{HD-Zip I subfamily gene expression in soybean subjected to drought}

\begin{abstract}
The objective of this work was to identify candidate genes of the HD-Zip I transcription factors subfamily that contribute to drought tolerance in soybean. Trifoliate soybean leaves of drought tolerant (Embrapa 48) and susceptible (BR 16) cultivars were evaluated under three levels of drought: absence, moderate (-1.5 MPa), and severe (-3.0 MPa). Promoter analysis indicated the presence of putative cis-regulatory elements related to water stress in the three genes evaluated (GmHB6, GmHB13, and GmHB21). However, there was no specific pattern of distribution associated with the higher drought tolerance of the genotype. By comparative analysis, six cis-regulatory elements potentially involved in the induction of gene expression under drought were identified. Gene $G m H B 13$ was exclusively induced by drought in the tolerant cultivar, and GmHB6 had its expression reduced only in the susceptible cultivar. Gene GmHB21 showed increased expression in both genotypes. Gene GmHB13 is an important element in the regulation of the drought tolerance mechanism in soybean, in the tolerant cultivar Embrapa 48.
\end{abstract}

Index terms: cis-regulatory elements, transcription factors, genomics, real time PCR.

\section{Introdução}

Atualmente, o Brasil ocupa o segundo lugar na produção mundial de soja (Glycine max L.) e, em cada safra, são registrados incrementos, tanto em área plantada, quanto na quantidade produzida. O levantamento da Companhia Nacional de Agricultura e Abastecimento, na safra 2009/2010, indicou incremento na área plantada de 1,5 milhão de hectares, equivalente a um aumento na produção de 10,7 milhões de toneladas, em relação à safra anterior (Companhia Nacional de Abastecimento, 2010). Entretanto, diversos fatores bióticos e abióticos, como nematoides, ferrugem asiática e seca, interferem na produtividade da soja (Yorinori et al., 2003; Wrather \& Koenning, 2006; Stolf-Moreira et al., 2010).

A ocorrência de seca tem-se tornado frequente, e, como boa parte da área plantada com soja utiliza variedade de ciclo precoce, as fases de florescimento e formação das vagens tornam-se mais seriamente prejudicadas pela estiagem (Companhia Nacional de Abastecimento, 2010). Em situações de deficit hídrico, vários mecanismos podem ser acionados pela planta para aumentar a tolerância à seca, embora apenas alguns deles tenham papel importante nessa resposta. Identificar genes induzidos somente em genótipos tolerantes pode auxiliar na identificação dos mecanismos principais de tolerância, o que possibilita novas alternativas de seleção

Pesq. agropec. bras., Brasília, v.46, n.8, p.884-889, ago. 2011 
genética para a tolerância à seca e a obtenção de plantas mais adaptadas a essa condição.

Genes que respondem aos estresses abióticos em nível transcricional têm sido identificados em várias plantas, e muitos deles têm papel importante na tolerância a esse estresse. Assim, a caracterização molecular da função desses genes, em diferentes estágios da resposta ao estresse, pode fornecer evidências dos genes envolvidos nessa resposta (Shinozaki \& Yamaguchi-Shinozaki, 2007). Além disso, a identificação de genes estresse-induzidos pode revelar funções essenciais ou importantes, com efeito na tolerância ou nas reações de defesa contra a perda de água (Talamè et al., 2007).

Diversos fatores de transcrição, como DREB (Shinozaki \& Yamagushi-Shinozaki, 2000), bZip (basic region leucine zipper), $M Y B, M Y C, N A C, W R K Y$ (Tran et al., 2007) e HD-Zip (Son et al., 2010), têm sido associados à tolerância ao deficit hídrico em plantas. Os fatores transcricionais da família $H D-Z i p$ são encontrados exclusivamente no reino vegetal e apresentam funções específicas no desenvolvimento das plantas (Son et al., 2010; Ré et al., 2011). Esses fatores de transcrição são caracterizados por apresentar dois domínios estruturais: o homeodomínio $(H D)$ e o zíper de leucina (Zip) (Elhiti \& Stasolla, 2009). A expressão dos genes da subfamília $H D$-Zip I de fatores transcricionais é regulada por fatores ambientais, como seca, altas temperaturas e estresse osmótico, e é específica em diferentes tecidos e órgãos da planta (Agalou et al., 2008; Elhiti \& Stasolla, 2009).

O objetivo deste trabalho foi identificar genes candidatos da subfamília de fatores transcricionais HD-Zip I que contribuem para a tolerância à seca em soja.

\section{Material e Métodos}

O experimento foi realizado em casa de vegetação com as cultivares de soja BR 16 (suscetível) e Embrapa 48 (tolerante), sob três níveis de deficit hídrico: ausência de estresse hídrico, potencial hídrico foliar $\left(\Psi_{\mathrm{w}}\right)$ entre $-0,1$ e $-0,3 \mathrm{MPa}$; estresse hídrico moderado, $\Psi_{\mathrm{w}}$ de -1,5 $\mathrm{MPa}$; e estresse hídrico severo, $\Psi_{\mathrm{w}}$ de $-3,0 \mathrm{MPa}$. O potencial hídrico das folhas foi avaliado com câmara de Scholander, na antemanhã. Trifólios de uma planta de cada cultivar foram coletados, embalados em papel alumínio e identificados com o genótipo, o tratamento, o tempo de coleta e o número da planta. Os materiais foram imersos imediatamente em nitrogênio líquido e mantidos em ultrafreezer a $-80^{\circ} \mathrm{C}$, para posterior extração de RNA.

A seleção dos genes que participam da resposta à seca foi baseada em revisão de literatura. Por se tratar de uma planta modelo, Arabidopsis thaliana foi escolhida como ponto de partida para obtenção das sequências dos genes referentes à subfamília $H D$-Zip I em soja. As sequências de nucleotídeos referentes à família HD-Zip em A. thaliana foram obtidas no National Center for Biotechnology Information (NCBI) (National Center for Biotechnology Information, 2008). As sequências de A. thaliana foram comparadas com o banco de dados Phytozome v3.1.1 (Phytozome, 2009), para se ter acesso ao genoma da soja. A busca no genoma da soja foi realizada com a ferramenta "Basic local alignment search tool" (BLASTn). O alinhamento das sequências da família $H D$-Zip em soja foi realizado com auxílio do programa Vector NTI (Invitrogen, Carlsbad, CA, EUA). Foi feito alinhamento somente da subfamília HD-Zip I de soja, para determinar a similaridade entre as sequências obtidas e quais oligonucleotídeos usar nas análises de PCR em tempo real.

A partir de 17 sequências de genes em $A$. thaliana referentes à subfamília $H D$-Zip I, presentes no NCBI, foram obtidas 16 sequências de genes em soja, com base na similaridade. Dessas 16 sequências, foram selecionadas oito para o sequenciamento dos oligonucleotídeos, e, a partir dos resultados obtidos pela análise de quantificação relativa, foram identificadas três sequências de genes para uso neste trabalho. (Tabela 1). As sequências dos oligonucleotídeos foram identificadas com auxílio do programa Primer Express Software 3.0 (Applied Biosystems, Carlsbad, CA, EUA), com o qual foram estabelecidos alguns

Tabela 1. Sequência dos genes utilizados da subfamília HD-Zip I em Arabidopsis thaliana e em soja (Glycine max), tamanho da sequência em pares de base (pb) e código de acesso no National Center for Biotechnology Information NCBI (2008) e no Phytozome (2009).

\begin{tabular}{lccc}
\hline Espécie & $\begin{array}{r}\text { Identificação } \\
\text { da sequência }\end{array}$ & $\begin{array}{c}\text { Tamanho da } \\
\text { sequência }(\mathrm{pb})\end{array}$ & $\begin{array}{c}\text { Código de acesso no NCBI } \\
\text { e no Phytozome }\end{array}$ \\
\hline A.thaliana & ATHB6 & 1.529 & NM_127808 \\
& ATHB13 & 1.401 & AF208044 \\
& ATHB21 & 1.205 & NM_126310 \\
\hline G. max & GmHB6 & 969 & Glyma18g01830.1 \\
& GmHB13 & 843 & Glyma08g40970.1 \\
& GmHB21 & 852 & Glyma07g40190.1 \\
\hline
\end{tabular}


parâmetros para favorecer a funcionalidade dos oligonucleotídeos desenhados. Após selecionar os pares de oligonucleotídeos que atendiam a essas condições, utilizou-se novamente o programa Vector NTI (Invitrogen, Carlsbad, CA, EUA), para verificar a formação de dímeros, dobramentos (hairpin) e força de ligação entre os oligonucleotídeos. Foram identificados oito pares de oligonucleotídeos referentes à subfamília $H D$-Zip $I$, relacionada ao estresse hídrico, sendo que neste trabalho foram utilizados três pares de oligonucleotídeos, com base nos resultados obtidos pela análise de quantificação relativa, e dois pares de controles endógenos (Tabela 2).

A extração de RNA total foi realizada conforme Chomczynski \& Sacchi (1987), com uso do reagente Trizol (Invitrogen, Carlsbad, CA, EUA), de acordo com as recomendações do fabricante. Todos os materiais utilizados foram previamente tratados com inibidor de RNAse (RNAse AWAY, Invitrogen, Carlsbad, CA, EUA). Foram extraídas três repetições das amostras de RNA dos trifólios de uma planta de cada cultivar. A integridade do RNA total foi analisada por eletroforese em gel de agarose a 1\%, com tampão TBE (Tris/ácido bórico/EDTA) 1x e corado com brometo de etídio. Foram adicionados ao gel de agarose $2 \mu \mathrm{L}$ de RNA com $2 \mu \mathrm{L}$ de tampão de amostra $40 \%$ sacarose.

A quantificação do RNA total foi realizada em espectrofotômetro nos comprimentos de ondas 260 e $280 \mathrm{~nm}$, cuja relação 260/280 fornece uma estimativa da pureza do ácido nucleico (Sambrook \& Russell, 2001). Utilizou-se como branco (controle interno e ausência de RNA) $\mathrm{H}_{2} \mathrm{O}$ tratada com DEPC $0,1 \%$ (dietilpirocarbonato). Posteriormente, as amostras de RNA foram tratadas com Dnase I (Invitrogen, Carlsbad,
CA, EUA), para remoção de possíveis resíduos de DNA genômico, de acordo com as recomendações do fabricante. Em seguida, o produto da reação foi armazenado a $4^{\circ} \mathrm{C}$ e usado posteriormente para as reações de PCR em tempo real.

As análises de PCR em tempo real foram realizadas no aparelho StepOnePlus (Applied Biosystems, Carlsbad, CA, EUA), no Laboratório de Fisiologia Molecular de Plantas, da Universidade Federal de Viçosa, com auxílio do programa StepOne Software v.2.0 (Applied Biosystems, Carlsbad, CA, EUA). Todas as reações foram submetidas às mesmas condições de análise e normalizadas pelo sinal do corante de referência passiva ROX Reference Dye (Invitrogen, Carlsbad, CA, EUA), para correção de flutuações na leitura decorrentes das variações de volume e evaporação ao longo da reação. Para todas as reações, foi utilizado o fluoróforo SYBR Green (Invitrogen, Carlsbad, CA, EUA).

Para avaliar a eficiência da reação de amplificação de cada oligonucleotídeo, foram realizadas diluições seriadas de cDNA (concentrado, 5x, 25x e 125x) para todos os pares de oligonucleotídeos e controles endógenos. Após verificar a eficiência dos genes, foram escolhidas a diluição do cDNA e a concentração dos oligonucleotídeos adequadas para preparar as reações da quantificação relativa. As amplificações foram realizadas em triplicatas.

$\mathrm{O}$ método $\Delta \Delta \mathrm{C}_{\mathrm{T}}$ foi utilizado para as análises de quantificação relativa. A reação e as condições da ciclagem da quantificação relativa foram as mesmas utilizadas nas análises de eficiência. Após a quantificação relativa, foi realizada uma etapa de curva de dissociação para verificar a formação de dímeros de oligonucleotídeos, amplificações inespecíficas,

Tabela 2. Sequência dos oligonucleotídeos e dos controles endógenos de soja utilizados nas reações de PCR em tempo real, temperatura média de anelamento (Tm) e tamanho dos fragmentos amplificado em pares de base (pb).

\begin{tabular}{lccc}
\hline Oligonucleotídeo & Sequência & Tm $\left({ }^{\circ} \mathrm{C}\right)$ & Tamanho do fragmento amplificado $(\mathrm{pb})$ \\
\hline GmHB6-Fw & 5' ACGATGGAACAAAGTAAGAGTGAC 3' & 53,1 & 114 \\
GmHB6-Rv & 5' GCAGTCGTCGTTGTTGTTGA 3' & 54,1 & 122 \\
GmHB13-Fw & 5' GCCAGAGATTCAGTGCCAAA 3' & 54,9 & 107 \\
GmHB13-Rv & 5' AATTGAAATGTTGCTGCTCCA 3' & 54,5 & 53,3 \\
GmHB21-Fw & 5' TCCACGGCACCTTCAAAT 3' & 49,2 & \\
GmHB21-Rv & 5' GCATGGTTCTTCAGGCA 3' & & 154 \\
\hline Controle endógeno & & 53,8 & 118 \\
rRNA18S-Fw & 5' AAACGGCTACCACATCCAAG 3' & 53,7 & \\
rRNA18S-Rv & 5' CCTTCAATGGATCCATCGTTA 3' & 53,6 & \\
$\beta$-actina-Fw & 5' GAGCTATGAATTGCCTGATGG 3' & 51,3 & \\
$\beta$-actina-Rv & 5' CGTTTCATGAATTCCAGTAGC 3' &
\end{tabular}

Pesq. agropec. bras., Brasília, v.46, n.8, p.884-889, ago. 2011 
possíveis erros e contaminações. A presença de um único pico de dissociação das fitas dos produtos da PCR foi considerada como evidência da especificidade da reação.

A identificação dos elementos cis-regulatórios foi feita por meio do banco de dados "Plant cis-acting regulatory DNA elements" (Place) (Higo et al., 1999). Os elementos cis-regulatórios foram selecionados por apresentar heterólogos com importantes funções na resposta à seca. Para isso, foram analisados 2.000 nucleotídeos acima da região 5 ' não traduzida, para cada gene encontrado.

\section{Resultados e Discussão}

Os genes GmHB6, GmHB13 e GmHB21 apresentaram eficiência de amplificação de 77, 86 e $98 \%$, respectivamente. Além disso, o gene $\beta$-actina, escolhido como gene de referência para as análises de quantificação relativa após avaliação no programa GeNorm (GeNorm, 2002), foi mais estável que os outros genes endógenos testados.

Foi observada uma expressão diferencial dos genes GmHB6, GmHB13 e GmHB21, em ambos os genótipos avaliados. A expressão do gene GmHB6 (Figura 1) é reduzida em ambos os genótipos, sob estresse hídrico. Entretanto, a redução é de apenas $20 \%$ na cultivar tolerante (Embrapa 48) sob estresse hídrico severo, e de aproximadamente 90\% na cultivar suscetível (BR 16). Em A. thaliana, o gene heterólogo é o ATHB6 que, ao contrário do observado em soja, é induzido sob seca

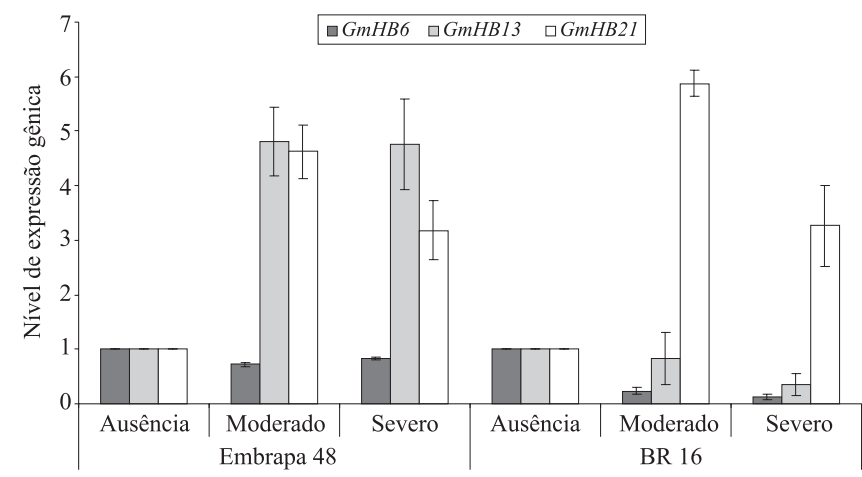

Figura 1. Nível de expressão dos genes $G m H B 6, G m H B 13$ e GmHB21 nas cultivares de soja Embrapa 48 (tolerante à seca) e BR 16 (suscetível à seca), sob três níveis de deficit hídrico: ausência de estresse hídrico (potencial hídrico entre $-0,1$ e $-0,3 \mathrm{MPa}$ ), estresse hídrico moderado (potencial hídrico de -1,5 MPa) e estresse hídrico severo (potencial hídrico de -3,0 MPa).
(Söderman et al., 1999) e é detectado, na epiderme, em gradiente, correlacionado ao padrão de divisão e diferenciação celular (Lee et al., 2001). A função da redução da expressão desse gene em soja pode estar associada à redução do desenvolvimento da parte aérea, o que reduz a área foliar e, consequentemente, a transpiração total, uma das mais rápidas respostas fisiológicas ao deficit hídrico. A redução da área foliar permite alocar mais fotoassimilatos para a raiz, que pode explorar maior profundidade e volume de solo e, portanto, repor mais rapidamente a água perdida por transpiração (Tardieu et al., 2000). Essa redução no crescimento das folhas está intimamente relacionada à redução na atividade de divisão celular (Tardieu et al., 2000). Como a maior redução na expressão desse gene ocorre na cultivar não tolerante, não é possível excluir a hipótese do papel do gene GmHB6 na tolerância da cultivar Embrapa 48. Evidências diretas para esse papel poderiam ser obtidas com a expressão antissenso desse gene.

Houve aumento de aproximadamente 4,8 vezes na expressão do gene $G m H B 13$ (Figura 1) na cultivar tolerante, quando submetido ao estresse, o que foi observado a partir do estresse hídrico moderado. Na cultivar suscetível, houve redução de $65 \%$ na expressão do gene sob estresse hídrico severo. Henriksson et al. (2005) observaram que a superexpressão do gene heterólogo $A T H B 13$, fusionado ao promotor constitutivo $35 \mathrm{~S}$ em plantas de $A$. thaliana, tornou as plantas mais tolerantes ao estresse hídrico. Segundo Hanson et al. (2001), o gene ATHB 13 também está relacionado a alterações nos níveis de açúcar nas folhas e em cotilédones em desenvolvimento. Esses autores verificaram que plantas transformadas com esse gene tiveram o fenótipo alterado somente quando a sacarose exógena era aplicada. O gene ATHB13 é expresso na parte aérea da planta, e seu padrão de expressão é semelhante, tanto em A. thaliana como em tomate (Lycopersicon esculentum Mill.). O gene homeobox de tomate $V A H O X 1$ é expresso em células do floema, mas, ao contrário do gene $A T H B 13$, a expressão do $V A H O X 1$ está localizada em caules maduros e não é expressa em folhas (Tornero et al., 1996).

Observou-se aumento na expressão do gene GmHB21 sob condição de seca (Figura 1), em ambos os genótipos. No entanto, o aumento de expressão foi de aproximadamente quatro e três vezes na cultivar tolerante, quando submetida à estresse de $-1,5$ e $-3,0 \mathrm{MPa}$, respectivamente, enquanto, na cultivar suscetível, o aumento foi de aproximadamente seis 
e três vezes. Henriksson et al. (2005) obtiveram resultados semelhantes para $A$. thaliana. Segundo esses autores, houve aumento de duas vezes na expressão do gene heterólogo $A T H B 21$ quando submetido à seca, o qual está presente em todos os tecidos da planta. Como os fatores HD-Zip agem como dímeros, tanto homoquanto heterodímeros, não é possível excluir a hipótese de que o fator transcricional GmHB21 tenha um papel na tolerância da cultivar Embrapa 48. Evidências diretas podem ser obtidas com a expressão antissenso desse gene, nesse genótipo.

Muitos genes relacionados à tolerância da planta à seca podem ter sua expressão induzida em nível transcricional. Contudo, essa ativação pode ocorrer em diferentes períodos. A cultivar tolerante demora mais tempo, sob restrição hídrica, para atingir o $\Psi_{w}$ de $-3,0$ MPa. Novos experimentos com diferentes dinâmicas de imposição da deficiência hídrica poderiam fornecer evidências mais detalhadas sobre o papel desse gene na tolerância à seca.

A análise dos elementos cis-regulatórios no banco de dados Place permitiu identificar diferenças nas sequências genômicas dos genes $G m H B 6, G m H B 13$ e GmHB21 (Figura 2). O gene não induzido ( $G m H B 6$ ), em contraste com os genes induzidos pelo estresse hídrico (GmHB13 e GmHB21), não apresenta os elementos cis-regulatórios ACGTATERD1, MYB2AT, MYB2CONSENSUSAT, DPBFCOREDCDC3,

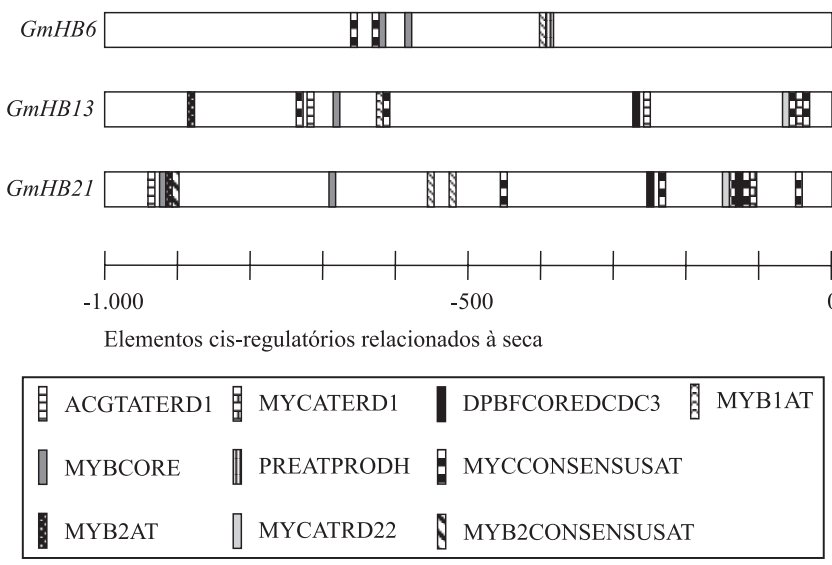

Figura 2. Localização dos elementos cis-regulatórios relacionados à tolerância à seca em soja, na região promotora dos genes GmHB6, GmHB13 e GmHB21. Os elementos cis-regulatórios identificados foram mapeados para permitir comparações entre as regiões promotoras dos genes. A escala representa a posição dos elementos, em relação ao início da região promotora dos genes.
MYCATERD1 e MYCATRD22. Esses elementos cis-regulatórios poderiam ser elementos envolvidos na indução da expressão dos genes $G m H B 13$ e $G m H B 21$ (Higo et al., 1999). Como são desconhecidas possíveis alterações nas sequências do promotor do gene $G m H B 13$ na cultivar tolerante e suscetível, não se pode excluir a possibilidade de que a ausência de algum elemento cis-regulatório no promotor desse gene, na cultivar suscetível, possa ser a causa da ausência de indução desse gene. Alternativamente, diferenças nas sequências não traduzidas (5' e $3^{\prime}$ ) poderiam diferir entre esses genes e afetar a estabilidade desse transcrito, a qual seria menor na cultivar suscetível (Casagrande et al., 2001). Outra possível explicação seria a menor expressão de algum fator transcricional que controla a expressão desse gene na cultivar suscetível (Eulgem, 2005). A identificação de elementos cis-regulatórios candidatos a regular a indução da expressão em resposta à seca permite realizar experimentos com deleções no promotor dos genes GmHB13 e GmHB21, para identificar elementos cis-regulatórios importantes na resposta à seca em soja.

\section{Conclusões}

1. O gene GmHB13 é importante na regulação da resposta de tolerância à seca, na cultivar tolerante Embrapa 48.

2. O gene GmHB6 contribui na resposta de tolerância à seca, na cultivar tolerante Embrapa 48.

\section{Agradecimentos}

À Coordenação de Aperfeiçoamento de Pessoal de Nível Superior e à Fundação de Amparo à Pesquisa do Estado de Minas Gerais, pelo apoio financeiro; ao Conselho Nacional de Desenvolvimento Científico e Tecnológico, pelo financiamento do projeto Genosoja; à Rosilene Mesquita, pelo apoio na condução do experimento; e ao Valdir Diola, pelo auxílio nas análises de PCR em tempo real.

\section{Referências}

AGALOU, A.; PURWANTOMO, S.; OVERNÄS, E.; JOHANNESSON, H.; ZHU, X.; ESTIATI, A.; DE KAM, R.J.; ENGSTRÖM, P.; SLAMET-LOEDIN, I.H.; ZHU, Z.; WANG, M.; XIONG, L.; MEIJER, A.H.; OUWERKERK, P.B. A genome-wide survey of HD-Zip genes in rice and analysis of drought-responsive family members. Plant Molecular Biology, v.66, 87-103, 2008. 
CASAGRANDE, E.C.; FARIAS, J.R.B.; NEUMAIER, N.; OYA, T.; PEDROSO, J.; MARTINS, P.K.; BRETON, M.C.: NEPOMUCENO, A.L. Expressão gênica diferencial durante déficit hídrico em soja. Revista Brasileira de Fisiologia Vegetal, v.13, p.168-184, 2001.

CHOMCZYNSKI, P.; SACCHI, N. Single-step method of RNA isolation by acid guanidinium thiocynate-phenol-chloroform extraction. Analytical Biochemistry, v.162, p.156-159, 1987.

COMPANHIA NACIONAL DE AGRICULTURA E ABASTECIMENTO. Soja-Brasil: série histórica de área plantada: safras 1976/77 a 2009/10. Disponível em: <http://www.conab.gov. br/conabweb/download/safra/SojaSerieHist.xls $>$. Acesso em: 20 maio 2010.

ELHITI, M.; STASOLLA, C. Structure and function of homodomain-leucine zipper (HD-Zip) proteins. Plant Signaling and Behavior, v.4, p.86-88, 2009.

EULGEM, T. Regulation of the Arabidopsis defense transcriptome. Trends in Plant Science, v.10, p.7178, 2005.

GENORM. Normalization of real-time PCR expression data. 2002. Available at: $<$ http://medgen.ugent.be/ judesomp/genorm $>$. Accessed on: 30 July 2009.

HANSON, J.; JOHANNESSON, H.; ENGSTROM, P. Sugar-dependent alterations in cotyledon and leaf development in transgenic plants expressing the HDZhdip gene ATHB13. Plant Molecular Biology, v.45, p.247-262, 2001.

HENRIKSSON, E.; OLSSON, A.S.B.; JOHANNESSON, H.; HANSON, J.; ENGSTROM, P.; SODERMAN, E. Homeodomain leucine zipper class I genes in Arabidopsis. Expression patterns and phylogenetic relationships. Plant Physiology, v.139, p.509-518, 2005.

HIGO, K.; UGAWA, Y.; IWAMOTO, M.; KORENAGA, T. Plant cis-acting regulatory DNA elements (PLACE) database: 1999. Nucleic Acids Research, v.27, p.297-300, 1999.

LEE, Y.H.; OH, H.S.; CHEON, C.I.; HWANG, I.T.; KIM, Y.J.; CHUN, J.Y. Structure and expression of the Arabidopsis thaliana homeobox gene $A T H B-12$. Biochemical and Biophysical Research Communications, v.284, p.133-141, 2001.

NATIONALCENTERFORBIOTECHNOLOGYINFORMATION. National Center for Biotechnology Information [home page]. Available at: <http://www.ncbi.nlm.nih.gov>. Accessed on: 30 Dec. 2008.

PHYTOZOME. Phytozome. Version 3.1.1. Available at: <http:// www.phytozome.net>. Accessed on: 21 Jan. 2009.

RÉ, D.A.; DEZAR, C.A.; CHAN, R.L.; BALDWIN, I.T.; BONAVENTURE, G. Nicotiana attenuata NaHD20 plays a role in leaf ABA accumulation during water stress, benzylacetone emission from flowers, and the timing of bolting and flower transitions. Journal of Experimental Botany, v.62, p.155-166, 2011.

SAMBROOK, J.; RUSSELL, D.W. Molecular cloning: a laboratory manuaL. 3.ed. New York: Cold Spring Harbor, 2001. 2344p.
SHINOZAKI, K.; YAMAGUCHI-SHINOZAKI, K. Gene networks involved in drought stress response and tolerance. Journal of Experimental Botany, v.58, p.221-227, 2007.

SHINOZAKI, K.; YAMAGUCHI-SHINOZAKI, K. Molecular responses to dehydration and low temperature: differences and cross-talk between two stress signaling pathways. Current Opinion in Plant Biology, v.3, p.217-223, 2000.

SÖDERMAN,E.;HJELLSTRÖM,M.;FAHLESON,J.;ENGSTRÖM, P. The HD-Zip gene ATHB6 in Arabidopsis is expressed in developing leaves, roots and carpels and up-regulated by water deficit conditions. Plant Molecular Biology, v.40, p.1073-1083, 1999.

SON, O.; HUR, Y.-S.; KIM, Y.-K.; LEE, H.-J.; KIM, S.; KIM, M.-R.; NAM, K.H.; LEE, M.S.; KIM, B.-Y.; PARK, J.; LEE, S.-C.; HANADA, A.; YAMAGUCHI, S.; LEE, I.-J.; KIM, S.-K.; YUN, D.-J.; SÖDERMAN, E.; CHEON, C.I.ATHB12, an ABA-inducible homeodomain-leucine zipper (HD-Zip) protein of Arabidopsis, negatively regulates the growth of the inflorescence stem by decreasing the expression of a Gibberellin 20-oxidase gene. Plant and Cell Physiology, v.51, p.1537-1547, 2010.

STOLF-MOREIRA, R.; MEDRI, M.E.; NEUMAIER, N.; LEMOS, N.G.; PIMENTA, J.A.; TOBITA, S.; BROGIN, R.L.; MARCELINO-GUIMARÃES, F.C.; OLIVEIRA, M.C.N.; FARIAS, J.R.B.; ABDELNOOR, R.V.; NEPOMUCENO, A.L. Soybean physiology and gene expression during drought. Genetics and Molecular Research, v.9, p.1946-1956, 2010.

TALAMÈ, V.; OZTURK, N.Z.; BOHNERT, H.J.; TUBEROSA, R. Barley transcript profiles under dehydration shock and drought stress treatments: a comparative analysis. Journal of Experimental Botany, v.58, p.229-240, 2007.

TARDIEU, F.; REYMOND, M.; HAMARD, P.; GRANIER, C.; MULLER, B. Spatial distributions of expansion rate, cell division rate and cell size in maize leaves: a synthesis of the effects of soil water status, evaporative demand and temperature. Journal of Experimental Botany, v.51, p.1505-1514, 2000.

TORNERO, P.; CONEJERO, V.; VERA, P. Phloem-specific expression of a plant homeobox gene during secondary phases of vascular development. The Plant Journal, v.9, p.639-648, 1996.

TRAN, L.-S.P.; NAKASHIMA, K.; SAKUMA, Y.; OSAKABE, Y.; QIN, F.; SIMPSON, S.D.; MARUYAMA, K.; FUJITA, Y.; SHINOZAKI, K.; YAMAGUCHI-SHINOZAKI, K. Co-expression of the stress-inducible zinc finger homeodomain ZFHD1 and NAC transcription factors enhances expression of the ERD1 gene in Arabidopsis. The Plant Journal, v.49, p.46-63, 2007.

WRATHER, J.A.; KOENNING, S.R. Estimates of disease effects on soybean yields in the United States 2003 to 2005. Journal of Nematology, v.38 p.173-180, 2006.

YORINORI, J.T.; PAIVA, W.M.; FREDERICK, R.D.; COSTAMILAN, L.M.; BERTAGNOLLI, P.F.; HARTMAN, G.L.; GODAY, C.V.; NUNES, J.J. Epidemics of soybean rust (Phakopsora pachyrhizi) in Brazil and Paraguay from 2001 to 2003. Plant Disease, v.89, p.675-677, 2003.

Recebido em 28 de fevereiro de 2011 e aprovado em 16 de agosto de 2011 